\title{
Fostering Resilience \\ Empowering rural communities in the face of hardship
}

Gateways: International Journal of Community Research and Engagement Vol 3 (2010): 55-69 CUTSePress and the authors

ISSN 1836-3393

\section{Darryl Maybery Gene Hodgins \\ Monash University \\ Rod Pope \\ Charles Sturt University \\ Charles Sturt University \\ Yvonne Hitchenor \\ North East Riverina Rural Counselling Service}

Statistics for rural and remote communities in Australia make for grim reading. The people in these communities experience relatively high unemployment, low household incomes, inadequate public transport, scarce services and an ageing population (Catholic Welfare Australia 2006). Coming on top of these difficulties has been the current Australian drought, which has been unprecedented in terms of its severity, geographic spread and duration, with some areas declared to be in '... exceptional circumstances for 13 of the past 16 years' (Productivity Commission, Australia 2008). The 'natural cause' of this economic loss has left communities struggling, as they attempt to respond to a situation that is largely beyond their control. In many cases this has led to a decline in rural community populations, with many members seeking better incomes and circumstances elsewhere (Country Matters 2008).

Recently, the Australian government established a Drought Policy Review Expert Social Panel to examine the social impact of drought on rural communities. During 2008, the panel held 25 public meetings with over 1000 people in order to gain feedback on the challenges facing these communities and, most importantly, to gather information to develop guidelines for the future. Among the multiple recommendations, the panel noted, 'To effectively prepare communities for the social impacts of future dryness, governments must ensure [that] support of community development initiatives reinforce social changes that will endure' (DPRESP 2008, p. 26). While outlining many positive interventions and responses to these communities, the panel also highlighted that 'There are a range of individuals and non-government welfare or church-based groups that are almost competing with each other to deliver packages of food, clothing or toiletries and to hold community socialising events' (p. 26). Further to this, 'A number of people informed the panel that, in their view, many of these groups may have lost sight of their client group' (p. 26).

In this article we report on findings generated from community meetings held as part of the community resilience building approach used by the North East Riverina Rural 
Counselling Service (NERRCS). While it is not unusual to capture information about the impact of climate on rural areas from public meetings or forums (such as the Expert Social Panel, 2008), this study uniquely focused on capturing community responses about what actions and goals they would propose, in order to build and strengthen their communities for the future. Contrary to being 'out of touch' and 'losing sight of their client group', the NERRCS approach is specifically designed to focus and empower small rural communities, families and individuals to self-manage the ongoing impact of adverse climate changes. The project was funded by the Australian Government Department of Families, Housing, Community Services and Indigenous Affairs (FaHCSIA), and focused on eight small communities in the south-east of New South Wales, Australia. This article details the key outcomes from the community meetings held in these regional areas, plus provides a discussion of the strengths and limitations of the research. It was considered that the core themes (from community responses) would provide important information and perhaps direction to other communities, policy makers and researchers seeking to encourage social groups struggling to build their resilience.

\section{THE NERRCS APPROACH}

The broad aim of the NERRCS approach was to support and build capacity in rural communities so that they could effectively manage change and thrive. The approach was initially developed from a community forum with practical input from a regional reference group and rural health academics from the Centre for Inland Health, Charles Sturt University, Wagga, New South Wales, and Monash University, Melbourne, Victoria. Central to the approach was increasing community access to and use of services offered by government and other agencies. It was recognised that rural people preferred to create their own destiny rather than have programs imposed on them. The project was designed, therefore, to empower small communities, with the secondary benefit of avoiding dependency. Community members would be invited to work together and plan community capacity building measures that would help them cope with the effects of drought. A series of community meetings were central to the NERRCS strategy.

The approach is strengths based, focusing on community assets and strengths rather than deficiencies and weaknesses in accordance with the principles of asset-based community development (Scales \& Streeter 2004). The NERRCS approach is also informed by the model of neighbourhood resilience described by Mowbray and colleagues (2007), and employs principles that underpin family and community centred practices (Dempsey \& Keen 2008; Dunst, Trivette \& Hamby 2007), which recognise that communities are unique, know the needs of their members best and are most able to support themselves. The concept of resilience has provided a valuable theoretical foundation on which to build the resulting approach to facilitating positive community responses to hardship. 
Definitions of resilience have included successful adaptation to stressful circumstances (Werner \& Smith 1982), the ability of individuals at high risk to prosper (Rutter 1987) and 'bungy jumping through life' (Fuller, McGraw \& Goodyear 1999, p. 159). Resilience involves such things as inner strengths like optimism, self-esteem and adaptive coping techniques (Grotberg 1995), and relational strengths characterised by having and maintaining quality supports and connections (Grotberg 1995). Relational resilience involves quality family connections (Resnick, Harris \& Blum 1993), availability of support (Cohen \& Wills 1985) and positive educational institutions and experiences (Fuller et al. 1999; Resnick, Harris \& Blum 1993). Luthar (2006, p. 780), a distinguished expert in the field, sums up five decades of research into resilience by saying that 'Resilience rests, fundamentally, on relationships ... strong supportive relationships are critical for achieving and sustaining resilient adaptation'.

While there has been considerably less research into community resilience, per se, than into individual resilience, Landau and Saul (2004) identify four themes important to community resilience in response to natural disasters and traumas. They include community and social connectedness; collective communication regarding the trauma; 'getting back on the horse [by] reestablishing the rhythms and routines of life'; and having a positive vision of the future or renewed hope. Mowbray and colleagues (2007) highlight connectedness to others through social assets, such as schools and sporting clubs in urban neighbourhoods, as being very important for community resilience. Being strengths focused is also an underlying ideal of the resilience concept. Landau (2007, p. 351) suggests that '... individuals, families, and communities are inherently competent and resilient, and that with appropriate support and encouragement, they can access individual and collective strengths that will allow them to transcend their loss'. This is the underlying premise of the NERRCS approach and is inherent within its strategic response to the small rural communities it serves.

In summary, it appears critical that interventions for Australian rural communities, which face perhaps the most difficult period in their history, must focus on empowerment from within rather than answers imposed from without. It also appears theoretically and anecdotally important that these solutions be socially proficient - that is, they build upon the social connections and resources already present in these communities to further develop their social resources.

\section{METHOD}

\section{Context}

The study was conducted in eight small rural communities, ranging in population size from approximately 150 to 8000 . These communities are all located within the northern Riverina region of New South Wales, Australia, in an area spreading 50-220 
$\mathrm{km}$ north and west of Wagga Wagga. This is part of the service delivery region of NERRCS. Wagga Wagga is a large regional centre (population just under 60 000), located $450 \mathrm{~km}$ south-west of Sydney. ARIA+ index scores for the participating communities ranged between 2.40 and 10.53, meaning these communities were categorised as 'outer regional' to 'remote' (Australian Institute of Health \& Welfare 2004).

\section{Participants}

Participants were 97 consenting members from the eight communities who, following open invitations to all community members, attended two meetings in their community organised by NERRCS. On this basis, it is unlikely that the participants were representative of all community members, but it is likely that they reasonably represented those community members most likely to participate in action to strengthen their communities, as attested by their attendance at the meetings. All participants were informed of the nature and purpose of this study, which formed part of the evaluation of the NERRCS program and meetings. All volunteered to participate on the understanding that the data required for the study would be gathered during the meeting proceedings, and that the anonymity of individuals would be protected. Participants were informed through extensive local advertising, including posters, newsletters and word of mouth, that the gatherings aimed to enlist local input to community planning and action that would strengthen the community.

\section{Ethics}

The study protocol was approved by the Charles Sturt University Ethics in Human Research Committee (Protocol 2008/133). Given the positive (strengths) focus of the approach and the voluntary nature of participation there was minimal risk to participants. However, we offered support service contact to participants and any description of participants ensured that they were not identifiable by their position in their communities. To take part in the community meetings, or focus groups, participants signed consent forms that were stored separately from all other material associated with the study, such as recordings, memo notes and transcripts. Any identifying information emerging at any time was removed from the data sets. The study did not, as far as we are aware, impinge on culturally sensitive issues or involve culturally and linguistically diverse participants or persons with mental illness. The ethical considerations of the research were consistent with those applying to many qualitative research projects, and included participant recruitment, informed consent, confidentiality and anonymity, protection from harm, and interpretation and ownership. These considerations were managed in accordance with the ethical guidelines identified by Charles Sturt University's Code of Conduct for Research. 


\section{Procedure}

Participants attended an initial interactive public meeting in their community, akin to a focus group, followed by a second 'action plan' meeting 6-10 weeks later. Both meetings were facilitated by NERRCS. The initial meeting encouraged attendees to identify and prioritise their needs, identify the community assets available to respond to those needs and identify skills gaps and barriers that must be addressed. The second meeting encouraged participants to prepare action plans that would strengthen their community and address identified needs. In line with the earlier mentioned philosophy of NERRCS - communities are unique, know best the needs of their members and are most able to support themselves - the discussion at both meetings in each community was very much 'led' by the community and not the facilitators. The meetings were guided by the following four key research questions (posed to each community):

-What are some of the issues/things that you are noticing here that you feel are a result of the drought?

-What does your community need to do if it is to become stronger?

-To implement an action plan to strengthen your community, what training and/or other supports do you need?

-What actions and future goals should your community undertake to become stronger?

\section{Data Collection}

Data was collected in two ways, with consent of all participants. First, large write-up sheets ('butchers paper') were employed to record, in writing that could be viewed by all participants, key points from the discussion. Second, the proceedings were audio recorded in order to capture the detail of the discussions.

\section{Data Analysis}

Following the meetings, both sources of data were then summarised for each community in the form of a brief report (6-8 pages), including action plans (see examples in Appendix 1). All documents were returned to the communities for participant checks (Lincoln \& Guba, 1985), in order to elicit feedback on any inaccuracies and required amendments. Key themes from the eight individual community reports were then independently identified by two authors for each of the four questions. These authors then pooled shared theme categories, noting differences but reaching an overall consensus regarding central themes.

\section{RESULTS}

Tables 1 to 4 outline the key responses to each of the four research questions, with communities listed as ' $\mathrm{A}$ ' through to ' $\mathrm{H}$ '. To the first question regarding the impact of the drought, Table 1 presents six key themes: finances, transport, stress and health, social disintegration, young people and community events (in this case, generally a positive outcome associated with events that brought the community together). 
Table 1: 'What are some of the issues/things that you are noticing here that you feel are a result of the drought?'
There were three subthemes within the 'financial impact of the drought' category: a general expression of having less money ('no money in your pocket'); the subsequent need for people to find off-farm jobs to supplement income; and the cost of transport. This issue of cost of transport (particularly in relation to higher fuel costs) was also considered important in relation to reducing social activity. Participants across a number of communities thought that the cost of transport meant that fewer people joined in sporting or other social activities, or volunteered for community activities.

Transport was also specifically mentioned in relation to accessing services such as health and education, but was also seen as a broader reflection of the 'Tyranny of Distance' suffered by rural communities. In distilling the comments, it appeared that transport was a 'rural issue', irrespective of the drought. However, the effect of the drought in reducing income and, in recent times, the increasing cost of fuel meant there was essentially a double negative impact on the ability to fund travel costs.

\begin{tabular}{|c|c|c|c|c|c|c|c|c|}
\hline \multirow[t]{2}{*}{ Town } & \multicolumn{3}{|c|}{ Financial impact of drought } & \multirow[t]{2}{*}{ Transport } & \multirow{2}{*}{$\begin{array}{l}\text { Stress and } \\
\text { health }\end{array}$} & \multirow{2}{*}{$\begin{array}{l}\text { Social } \\
\text { disintegration }\end{array}$} & \multirow[t]{2}{*}{ Young people } & \multirow{2}{*}{$\begin{array}{l}\text { Community } \\
\text { events } \\
\text { (positive) }\end{array}$} \\
\hline & General & Off-farm work & $\begin{array}{l}\text { Fuel costs - } \\
\text { social contact }\end{array}$ & & & & & \\
\hline A & $\begin{array}{l}\text { No money } \\
\text { to spend. } \\
\text { Affecting } \\
\text { business and } \\
\text { businesses } \\
\text { closing. }\end{array}$ & $\begin{array}{l}\text { Farmers } \\
\text { working 'off } \\
\text { farm' for } \\
\text { income. }\end{array}$ & $\begin{array}{l}\text { Really hard to } \\
\text { find money to } \\
\text { do things. }\end{array}$ & & & $\begin{array}{l}\text { Going outside } \\
\text { of town, 'living } \\
\text { away from } \\
\text { home base'. } \\
\text { Volunteers } \\
\text { are burning } \\
\text { out, giving up } \\
\text { commitments. }\end{array}$ & $\begin{array}{l}\text { Numbers } \\
\text { of children } \\
\text { dropping } \\
\text { (no farming } \\
\text { children) } \\
\text { - have been } \\
\text { decreasing } \\
\text { since 1980s. } \\
\text { Fewer activities } \\
\text { locally for } \\
\text { children - now } \\
\text { going to bigger } \\
\text { centres. }\end{array}$ & $\begin{array}{l}\text { One particular } \\
\text { annual major } \\
\text { event of this } \\
\text { community } \\
\text { is good for } \\
\text { the town. } \\
\text { Community } \\
\text { drought } \\
\text { gatherings and } \\
\text { witches night } \\
\text { have been } \\
\text { good. }\end{array}$ \\
\hline B & $\begin{array}{l}\text { Unemployment } \\
\text { - rural and } \\
\text { regional. Fifty } \\
\text { per cent less } \\
\text { income in Shire } \\
\text { since } 2001 . \\
\text { Slower retail } \\
\text { economy. }\end{array}$ & & $\begin{array}{l}\text { Fewer dollars } \\
\text { in community } \\
\text { - less joining } \\
\text { in things like } \\
\text { sport etc. }\end{array}$ & & $\begin{array}{l}\text { Strain on } \\
\text { existing } \\
\text { facilities; } \\
\text { mental, } \\
\text { physical, } \\
\text { emotional. } \\
\text { Children } \\
\text { impacted (they } \\
\text { know what is } \\
\text { going on and } \\
\text { are feeling } \\
\text { the strain). } \\
\text { Negativity, } \\
\text { frustration. }\end{array}$ & $\begin{array}{l}\text { Social } \\
\text { interaction } \\
\text { decreasing. }\end{array}$ & $\begin{array}{l}\text { Kids not } \\
\text { coming } \\
\text { to town. } \\
\text { Declining } \\
\text { student } \\
\text { numbers } \\
\text { (TAFE), } \\
\text { especially in } \\
\text { rural courses. }\end{array}$ & \\
\hline $\mathrm{C}$ & $\begin{array}{l}\text { Financial } \\
\text { impacts on } \\
\text { individuals, } \\
\text { families, } \\
\text { business } \\
\text { and the } \\
\text { community. }\end{array}$ & & & & $\begin{array}{l}\text { Health issues, } \\
\text { including } \\
\text { access to } \\
\text { doctors } \\
\text { (depression, } \\
\text { hidden } \\
\text { feelings). }\end{array}$ & $\begin{array}{l}\text { Volunteers } \\
\text { burning out. } \\
\text { Friendly town. } \\
\text { Incoming } \\
\text { people are } \\
\text { welcomed +/- }\end{array}$ & $\begin{array}{l}\text { People } \\
\text { leaving the } \\
\text { community, } \\
\text { particularly } \\
\text { young people. } \\
\text { School } \\
\text { numbers are } \\
\text { fine. }\end{array}$ & $\begin{array}{l}\text { Strong } \\
\text { sporting ties. }\end{array}$ \\
\hline
\end{tabular}


61 | Gateways | Maybery, Pope, Hodgins \& Hitchenor

\begin{tabular}{|c|c|c|c|c|c|c|c|c|}
\hline \multirow[t]{2}{*}{ Town } & \multicolumn{3}{|c|}{ Financial impact of drought } & \multirow[t]{2}{*}{ Transport } & \multirow{2}{*}{$\begin{array}{l}\text { Stress and } \\
\text { health }\end{array}$} & \multirow{2}{*}{$\begin{array}{l}\text { Social } \\
\text { disintegration }\end{array}$} & \multirow[t]{2}{*}{ Young people } & \multirow{2}{*}{$\begin{array}{l}\text { Community } \\
\text { events } \\
\text { (positive) }\end{array}$} \\
\hline & General & Off-farm work & $\begin{array}{l}\text { Fuel costs - } \\
\text { social contact }\end{array}$ & & & & & \\
\hline D & $\begin{array}{l}\text { Prolonged } \\
\text { nature of } \\
\text { drought. }\end{array}$ & & $\begin{array}{l}\text { Lack of income } \\
\text { and disposable } \\
\text { cash for } \\
\text { individuals } \\
\text { and families } \\
\text { within the } \\
\text { community. }\end{array}$ & & $\begin{array}{l}\text { Concern and } \\
\text { worry in terms } \\
\text { of future } \\
\text { weather. }\end{array}$ & $\begin{array}{l}\text { 'Town name } \\
\text { is changing'. } \\
\text { New people } \\
\text { moving to the } \\
\text { community } \\
\text { especially from } \\
\text { 'cities'. They } \\
\text { have different } \\
\text { ways of living } \\
\text { and different } \\
\text { expectations. }\end{array}$ & $\begin{array}{l}\text { Perception by } \\
\text { parents that } \\
\text { children will } \\
\text { be 'turned } \\
\text { off' pursuing } \\
\text { a career in } \\
\text { agriculture/ } \\
\text { farming. } \\
\text { Community is } \\
\text { ageing - fewer } \\
\text { children and } \\
\text { families - not } \\
\text { attracting } \\
\text { young families. }\end{array}$ & \\
\hline E & $\begin{array}{l}\text { People looking } \\
\text { for alternative } \\
\text { employment - } \\
\text { off farm. }\end{array}$ & $\begin{array}{l}\text { Requirement to } \\
\text { travel away for } \\
\text { training and } \\
\text { stay away from } \\
\text { home with low } \\
\text { wages. }\end{array}$ & $\begin{array}{l}\text { Social aspect } \\
\text { disappeared } \\
\text { as a result } \\
\text { of financial } \\
\text { restrictions. } \\
\text { Increased fuel } \\
\text { costs having } \\
\text { a real impact } \\
\text { - potential } \\
\text { to increase } \\
\text { isolation. }\end{array}$ & $\begin{array}{l}\text { Very limited } \\
\text { services and } \\
\text { having to } \\
\text { travel for } \\
\text { everything } \\
\text { - health, } \\
\text { education } \\
\text { etc. - placing } \\
\text { extra financial } \\
\text { burden. Some } \\
\text { services not } \\
\text { available } \\
\text { in local } \\
\text { community, so } \\
\text { need to travel } \\
\text { to Wagga } \\
\text { Wagga. }\end{array}$ & & $\begin{array}{l}\text { People } \\
\text { leaving the } \\
\text { community. } \\
\text { Social aspect } \\
\text { disappeared } \\
\text { as a result } \\
\text { of decreased } \\
\text { numbers of } \\
\text { residents. } \\
\text { Families } \\
\text { separated as } \\
\text { a result of } \\
\text { off-farm work } \\
\text { - dividing } \\
\text { families and } \\
\text { increasing } \\
\text { pressures in } \\
\text { families. }\end{array}$ & $\begin{array}{l}\text { Children } \\
\text { noticing } \\
\text { and missing } \\
\text { the social } \\
\text { side of the } \\
\text { community. } \\
\text { Sporting clubs } \\
\text { folding. }\end{array}$ & $\begin{array}{l}\text { Community } \\
\text { connection lost } \\
\text { in recent years, } \\
\text { e.g. closure of } \\
\text { Golf Club and } \\
\text { Tennis Club. }\end{array}$ \\
\hline $\mathbf{F}$ & $\begin{array}{l}\text { Financial } \\
\text { impacts. }\end{array}$ & & $\begin{array}{l}\text { Isolation due } \\
\text { to cost of } \\
\text { fuel: impact } \\
\text { on health. } \\
\text { Difficulties } \\
\text { with IPTAS } \\
\text { (Isolated } \\
\text { patient } \\
\text { transport } \\
\text { assistance } \\
\text { scheme). Guilt } \\
\text { of parents. } \\
\text { Extra pressure } \\
\text { on service } \\
\text { providers. }\end{array}$ & & $\begin{array}{l}\text { Depression. } \\
\text { Frustration - } \\
\text { not being able } \\
\text { to provide for } \\
\text { family. Loss of } \\
\text { control. Losing } \\
\text { confidence } \\
\text { in the future. } \\
\text { Lack of } \\
\text { motivation to } \\
\text { plan/decide. }\end{array}$ & $\begin{array}{l}\text { Exodus from } \\
\text { rural areas. } \\
\text { Family break- } \\
\text { down (com- } \\
\text { munication } \\
\text { breakdown). } \\
\text { Community } \\
\text { resilience in } \\
\text { evidence. } \\
\text { Volunteers de- } \\
\text { creased: num- } \\
\text { bers, ability, } \\
\text { financial and } \\
\text { psychological, } \\
\text { availability, } \\
\text { work demands, } \\
\text { tougher } \\
\text { existence. }\end{array}$ & & $\begin{array}{l}\text { Community } \\
\text { teamwork } \\
\text { to the fore. } \\
\text { Opportunit- } \\
\text { ies to teach } \\
\text { kids about } \\
\text { resilience, } \\
\text { teamwork. }\end{array}$ \\
\hline G & $\begin{array}{l}\text { Lack of } \\
\text { on-farm } \\
\text { jobs. Lack of } \\
\text { income - small } \\
\text { businesses } \\
\text { struggling. }\end{array}$ & $\begin{array}{l}\text { Having to get } \\
\text { other jobs. }\end{array}$ & & $\begin{array}{l}\text { Community } \\
\text { transport } \\
\text { needs (no } \\
\text { transportation } \\
\text { to bigger } \\
\text { centres). } \\
\text { 'Tyranny of } \\
\text { distance'; } \\
\text { tradespeople } \\
\text { not wanting to } \\
\text { come out. }\end{array}$ & $\begin{array}{l}\text { Lack of } \\
\text { motivation. } \\
\text { Depression } \\
\text { (individual) } \\
\text { - concern } \\
\text { children are } \\
\text { depressed as } \\
\text { well. }\end{array}$ & & $\begin{array}{l}\text { Losing young } \\
\text { people. Harder } \\
\text { for young } \\
\text { families to get } \\
\text { started. }\end{array}$ & \\
\hline
\end{tabular}


62 | Gateways | Maybery, Pope, Hodgins \& Hitchenor

\begin{tabular}{|c|c|c|c|c|c|c|c|c|}
\hline \multirow[t]{2}{*}{ Town } & \multicolumn{3}{|c|}{ Financial impact of drought } & \multirow[t]{2}{*}{ Transport } & \multirow{2}{*}{$\begin{array}{l}\text { Stress and } \\
\text { health }\end{array}$} & \multirow{2}{*}{$\begin{array}{l}\text { Social } \\
\text { disintegration }\end{array}$} & \multirow[t]{2}{*}{ Young people } & \multirow{2}{*}{$\begin{array}{l}\text { Community } \\
\text { events } \\
\text { (positive) }\end{array}$} \\
\hline & General & Off-farm work & $\begin{array}{l}\text { Fuel costs - } \\
\text { social contact }\end{array}$ & & & & & \\
\hline $\mathbf{H}$ & $\begin{array}{l}\text { No money in } \\
\text { your pocket. }\end{array}$ & $\begin{array}{l}\text { More women } \\
\text { working } \\
\text { off farm - } \\
\text { childcare } \\
\text { issues. Fuel is } \\
\text { dear here - } \\
\text { people have } \\
\text { to travel long } \\
\text { distances. }\end{array}$ & $\begin{array}{l}\text { Less people } \\
\text { with time } \\
\text { and money to } \\
\text { volunteer, but } \\
\text { more work to } \\
\text { do. }\end{array}$ & & $\begin{array}{l}\text { More } \\
\text { depression. } \\
\text { Feelings hidden } \\
\text { - failure? } \\
\text { Especially the } \\
\text { men. Middle } \\
\text { generation } \\
\text { suffering - } \\
\text { not as much } \\
\text { experience } \\
\text { of drought. } \\
\text { Stigma } \\
\text { attached to } \\
\text { poor mental } \\
\text { health. }\end{array}$ & $\begin{array}{l}\text { People leaving } \\
\text { farms/towns. } \\
\text { People helping } \\
\text { one another } \\
\text { out - coming } \\
\text { together more. }\end{array}$ & & \\
\hline
\end{tabular}

Table 2 highlights some typical statements from across the community groups in response to the second research question identifying what communities need to do to become stronger. The central theme that emerged was the desire for more social or recreational activities. This was notable, as almost all of the groups saw this as a key way to bring people from the community together. The second theme was the need to strengthen families, with a particular focus on young people - this included more social activities and the general perceived need to 'strengthen families to support kids'. There was some overlap of this category with the social/recreational category and also with the third category, which was to provide support/empathy to and between community members. Together, these three categories constitute

Table 2: What does your a shared theme of developing community connectedness and the community need to do if it is to become stronger? social assets of the community.

\begin{tabular}{|c|c|c|c|c|c|}
\hline Town & $\begin{array}{l}\text { Social/ } \\
\text { recreational }\end{array}$ & $\begin{array}{l}\text { Family/ } \\
\text { youth }\end{array}$ & $\begin{array}{l}\text { Support/ } \\
\text { empathy }\end{array}$ & $\begin{array}{l}\text { Organisational/ } \\
\text { visual/practical }\end{array}$ & Training \\
\hline A & More social events. & $\begin{array}{l}\text { More for the youth and } \\
\text { families. }\end{array}$ & & Town needs to look better. & \\
\hline B & Maintain contact. & & Understanding and listening. & & $\begin{array}{l}\text { Education, business } \\
\text { development. }\end{array}$ \\
\hline $\mathrm{C}$ & Hobby groups/clubs. & & Help each other. & & $\begin{array}{l}\text { TAFE outreach courses/ } \\
\text { computers. }\end{array}$ \\
\hline D & $\begin{array}{l}\text { Have regular organised gather- } \\
\text { ings. Socialise more. }\end{array}$ & & Community support. & Work together as a group. & \\
\hline E & Social gatherings. & & $\begin{array}{l}\text { Promote increased community } \\
\text { connectedness. }\end{array}$ & $\begin{array}{l}\text { Working bees to clean up } \\
\text { church yards etc. }\end{array}$ & $\begin{array}{l}\text { Provide resources to start } \\
\text { projects. }\end{array}$ \\
\hline$F$ & $\begin{array}{l}\text { More social events. } \\
\text { Involve farm and town people } \\
\text { together if possible. }\end{array}$ & $\begin{array}{l}\text { Strengthen families to support } \\
\text { kids. }\end{array}$ & $\begin{array}{l}\text { Encourage communication } \\
\text { and support between commu- } \\
\text { nity members. }\end{array}$ & $\begin{array}{l}\text { Funding and town } \\
\text { improvement. }\end{array}$ & \\
\hline G & Hobbies, sports etc. & Youth - social opportunities. & $\begin{array}{l}\text { Be more aware of others' } \\
\text { feelings. }\end{array}$ & Clean up after ourselves. & \\
\hline
\end{tabular}

The final two theme categories in participant responses were focused on such things as improving the look and function of the town (such as organisational/visual/ practical), and meeting the training needs of the community. Responses to Question 3 build upon this training need (see Table 3). 
63 | Gateways | Maybery, Pope, Hodgins \& Hitchenor

\begin{tabular}{|c|c|c|c|c|c|}
\hline Town & $\begin{array}{l}\text { Submission/ } \\
\text { grant writing }\end{array}$ & Short courses & Action planning & Enlist outside support & Other \\
\hline A & & & & Get shire assistance. & $\begin{array}{l}\text { Nothing needed - action } \\
\text { being taken within town } \\
\text { resources. }\end{array}$ \\
\hline B & $\begin{array}{l}\text { How to write funding } \\
\text { submissions and access } \\
\text { grants. }\end{array}$ & & $\begin{array}{l}\text { Support to write action } \\
\text { plan. }\end{array}$ & $\begin{array}{l}\text { Independent facilitator } \\
\text { for future meetings } \\
\text { (NERCCS). }\end{array}$ & $\begin{array}{l}\text { Develop interagency } \\
\text { collaboration. }\end{array}$ \\
\hline $\mathrm{C}$ & & & & $\begin{array}{l}\text { Get outside support from } \\
\text { local shire, youth work, } \\
\text { NERCCS, Lions, Rotary. }\end{array}$ & \\
\hline $\mathrm{D}$ & $\begin{array}{l}\text { Submission/grant } \\
\text { writing. }\end{array}$ & $\begin{array}{l}\text { How to run more effective } \\
\text { meetings and events. }\end{array}$ & How to plan. & & $\begin{array}{l}\text { Basic corporate } \\
\text { governance. }\end{array}$ \\
\hline E & & & & $\begin{array}{l}\text { Get funding from DPI } \\
\text { and/or catchment } \\
\text { management authority. }\end{array}$ & \\
\hline $\mathrm{F}$ & $\begin{array}{l}\text { Submission/grant } \\
\text { writing. }\end{array}$ & $\begin{array}{l}\text { Mental health and } \\
\text { wellbeing. First aid } \\
\text { update. Resumé writing. }\end{array}$ & & $\begin{array}{l}\text { Independent facilitator } \\
\text { for planned meeting } \\
\text { (NERCCS). } \\
\text { Draw on outsiders for } \\
\text { instrumental actions/ } \\
\text { support. }\end{array}$ & \\
\hline G & & & & $\begin{array}{l}\text { Independent facilitator } \\
\text { for community meeting } \\
\text { required. }\end{array}$ & \\
\hline
\end{tabular}

Table 3: To implement an action plan to strengthen your community, what training and/or other supports do you need?
The central training needs identified by participants were in submission and grant writing, short courses in such things as mental health and first aid updates, resumé writing and support on how to plan and undertake action planning. With the exception of one community, there was also an identified need to enlist outside support. In addition, almost half of the communities identified that an outside independent facilitator was important for planning and community meetings.

Further to this, and not shown in Table 3, participants also considered it important to have a local organiser who was readily accessible, knew 'what the community was already doing', and could ensure that the timing of such things as training was considerate of other work commitments. There was also interest in sharing community ideas with others.

The two most commonly articulated goals, each proposed by six communities, were centred on increasing social connectedness and being or becoming more positive in focus (see Table 4). Social connectedness focused upon bringing people together generally but also on getting the community working together and having fun. Being positive focused on developing a team spirit to build belonging and to overcome apathy. The remaining goals centred on providing support to others, particularly youth, welcoming visitors, improving the skills of community members and beautifying the town.

Based on these goals, each community then proceeded to develop a detailed action plan to address their goals. It is not possible, within the confines of this paper, to describe all of the actions proposed but examples are provided in Appendix 1 and illustrate the sorts of detailed and concrete planning that participants undertook for their communities. 
64 | Gateways | Maybery, Pope, Hodgins \& Hitchenor

\begin{tabular}{|c|c|c|c|c|c|c|}
\hline Town & $\begin{array}{l}\text { Social } \\
\text { connectedness }\end{array}$ & Be/come positive & Provide support & Visitors & Improve skills & Improve town \\
\hline A & $\begin{array}{l}\text { Bring people } \\
\text { together. }\end{array}$ & & Support our youth. & Welcome our visitors. & & Beautify our town. \\
\hline B & Working community. & $\begin{array}{l}\text { Overcome apathy to } \\
\text { empathy. Interested } \\
\text { community. }\end{array}$ & & & & \\
\hline $\mathrm{C}$ & & $\begin{array}{l}\text { Seek opportunity } \\
\text { and run with it. }\end{array}$ & $\begin{array}{l}\text { Support our } \\
\text { community. }\end{array}$ & $\begin{array}{l}\text { Increase visitors to } \\
\text { town. }\end{array}$ & & \\
\hline $\mathrm{D}$ & Social connectedness. & Team spirit. & Mutual support. & & & \\
\hline$E$ & $\begin{array}{l}\text { Bring people } \\
\text { together. }\end{array}$ & $\begin{array}{l}\text { Build a sense of } \\
\text { belonging. }\end{array}$ & & & $\begin{array}{l}\text { Skills for individuals. } \\
\text { Skills for community. }\end{array}$ & \\
\hline $\mathrm{F}$ & $\begin{array}{l}\text { Bring people } \\
\text { together, increase } \\
\text { opportunity and } \\
\text { diversity. }\end{array}$ & $\begin{array}{l}\text { Create positive } \\
\text { energy with positive } \\
\text { communication. }\end{array}$ & $\begin{array}{l}\text { Encourage and } \\
\text { support youth. }\end{array}$ & & & \\
\hline G & & $\begin{array}{l}\text { Create positive } \\
\text { energy. Overcome } \\
\text { apathy. }\end{array}$ & & & Skills training. & \\
\hline $\mathrm{H}$ & Family fun day. & & & & & \\
\hline
\end{tabular}

Table 4: What actions and future goals should your community undertake to become stronger?

\section{DISCUSSION}

Many communities in this study highlighted the stress and strain associated with the drought and the resultant mental health problems. This is consistent with previous research (for example, Alston \& Kent 2004; DPRESP 2008). The theme of halting disintegration and building social cohesion was a key need and action plan. This theme was also important for young people. While previous literature has shown how the drift of families away from rural communities impacts on young people's further education and schooling (Alston \& Kent 2006; DPRESP 2008), the current finding illustrates that rural communities are also concerned about the socially isolating nature of drought on young people.

An important finding from this study was the enthusiasm and empowerment that the NERRCS approach facilitated in the participating communities. The Appendix illustrates communities determining and taking action to meet their own identified needs, with multiple community members responding with action.

Landau and Saul (2004, p. 9) suggested, following the $9 / 11$ tragedy, that communities in New York needed the opportunity '... to be able to retain or regain connection to their families and natural support systems'. It appears that communities in the rural Australian context have similar needs. The NERRCS approach brought each participating community together and focused them on their strengths and natural support systems, via social activities.

However, unlike 9/11, the Australian drought experience is now not considered to be a defining event, but rather a normal part of Australian agriculture (DPRESP 2008). This definitional reorientation of drought prompts a need to examine how external agencies should respond to these communities. The NERRCS community empowerment approach, as demonstrated by the current findings, provides a model of how governments (and 
non-government agencies) can respond to the recent Expert Social Panel suggestion that, 'Governments must be more effective in encouraging people in rural communities to self-identify their health needs and be able to seek appropriate support at an early stage' (DPRESP 2008, p. 8). Instead of external agencies imposing themselves on communities (DPRESP 2008), we suggest a resilience model of community engagement that:

- focuses communities upon their strengths and natural support mechanisms

-inherently values the communities' strengths and ability to respond

—builds upon the communities' self-identified needs, activities and assets.

Such outcomes are clearly demonstrated by many of the community responses highlighted in Table 2. In responding to the question 'What does your community need to do if it is to become stronger', the communities highlighted four key strengths that could be built upon. Notably, only one factor (training) required outside support. While not suggesting that outside assistance should not be offered, this finding highlights that if given the opportunity (for example, via the NERRCS approach) communities will focus upon building and enhancing their own strengths and resources. We suggest that employing this approach is likely to lead to a more efficient, focused and effective use of external resources, one which is directed by communities.

The NERRCS approach could also be extended further. First, it could consider what mechanisms could be put in place to sustain engagement, empowerment and development of these communities. While some of the current NERRCS communities did not need further encouragement to focus and plan for the future, other communities appeared to need ongoing facilitation to nurture empowerment. A second issue is how to encourage early identification of issues, problems and solutions, using the NERRCS approach, in a continuous fashion. One mechanism might be for drought workers or counsellors to regularly facilitate such meetings with the communities they serve - akin to a town reference group that is attuned to recognising community needs and directing actions and utilising resources. We recommend that agencies, as a first step, engage with groups of individuals who are broadly representative of their community. Engagement with communities should be undertaken with a strength and resilience focus and attitude. This would ensure that individuals and organisations intending to serve communities do not 'lose sight of their client group'. It is particularly important to note that facilitators need to be independent of the communities, be strengths focused and be willing and able to facilitate community action and self-development.

There are several limitations to this research. First, the data collection relied upon groups of individuals who volunteered to attend a community meeting. While these meetings were open to 
the public, the findings may have been affected by sampling bias and participants responding in a group setting. Second, while considerable effort was made to reduce any facilitator bias (that is, facilitator awareness of the issues, philosophy of NERRCS), small rural communities are not isolated from one another, and they may have communicated action aims or outcomes to each other independently of the NERRCS-organised meetings.

In conclusion, the current findings are important in confirming some of the key issues of stress, strain and financial hardship in rural communities dealing with prolonged drought. However, most importantly, the findings demonstrated that, though the communities recognise that this situation is contributing to some degree of social disintegration, there appears to be considerable hope that, by working together and utilising social agencies, communities can develop social connectedness, which can in turn make them more resilient. The NERRCS approach is an important model that drought workers and governments can use to encourage rural communities to selfidentify their needs, strengths and assets; be empowered to take future action; and move forward in a coordinated fashion.

\section{ACKNOWLEDGEMENT}

We gratefully acknowledge the support of the North East Riverina Rural Counselling Service, Charles Sturt University Centre for Inland Health, and funding provided by the Australian Government Department of Families, Housing, Community Services and Indigenous Affairs.

\section{APPENDIX 1}

Examples of action planning and goal setting from Towns $\mathrm{D}$ and $\mathrm{E}$ (note that minimal editorial changes were made to these planning documents).

\section{Town D}

By consensus, the participants decided to focus on social connectedness (Goal 1) as it was felt that if Town D was a socially connected community this would foster mutual support (Goal 2) and team spirit (Goal 3).

\section{Our goal}

Organise a Community Christmas Celebration at the Recreation Ground.

- How: Find out who is interested - by newsletter, word of mouth, shop notice and personal contact. Enlist support.

-When: Sat 15th December at $5.30 \mathrm{pm}$ (TBC), planning done by 1st week in December.

-Who: Seven people were named as volunteers (noted that all others who show interest were welcome - the more the better). One person was named to talk to all who come into the Store.

-Resources: $\$ \$ \$ \$$ Budget $\$ 600$ : promotional flyer, inform and get permission from Recreation Ground and Show Society (Shire), get Public Liability Insurance - each of these activities were assigned 
a volunteer responsible for taking action. Get people to help; need kids' amusement ideas.

A final note: By this point in the process facilitation was redundant, as the participants had taken control of both the process and the event. They then presented their morning's work to the Year 6 pupils, seeking their involvement and feedback. The group agreed to meet again at the Store on Monday next in order to continue planning.

\section{Town E}

\section{Our goal}

To bring people together, increase opportunity and diversity with the aim of creating a music group/club.

- How: Approach arts council, develop the story behind the idea, use churches and schools to promote, identify and seek expressions of interest, write a story for the newspaper and local news.

-When: Discuss potential at next interagency meeting May 20.

-Who: Five volunteers were identified, with some actions required, including talking to Arts council and approaching a neighbouring community who had a choir.

- Resources: Draw on local government area to promote and find a venue; the Arts Council and local newspaper to help in promotion.

\section{REFERENCES}

Aisbett, D, Boyd, C, Francis, K, Newnham, K \& Newnham, K 2007, 'Understanding barriers to mental health service utilization for adolescents in rural Australia', Rural and Remote Health, vol. 7, no. 624.

Alston, M \& Kent, J 2004, Social impacts of drought: A report to NSW Agriculture, Centre for Rural Social Research, Charles Sturt University, Wagga Wagga, Australia.

Alston, M \& Kent, J 2006, The impact of drought on secondary education access for rural and remote areas. A report for DEST, Centre for Rural Social Research, Charles Sturt University, Wagga Wagga, Australia.

Australian Institute of Health and Welfare 2004, Rural, regional and remote health: A guide to remoteness classifications, Rural Health Series no. 4, cat. no. PHE 53, AIHW, Canberra.

Australian Institute of Health and Welfare 2007, Rural, regional and remote health: A study on mortality, 2nd edn, Rural Health Series no. 8, cat. no. PHE 95, AIHW, Canberra.

Catholic Welfare Australia 2006, Lessons from the field: Family relationship services in rural and remote Australia - challenges and good practice, discussion paper, Catholic Welfare Australia and the Department of Families, Community Services and Indigenous Affairs, Canberra, viewed 23 October 2008, www.fahcsia.gov.au/sa/families/pubs/rural remote/ lessons from field-frs rural remote aus/Pages/default.aspx.

Cohen, S \& Wills, T 1985, 'Stress, social support, and the buffering hypothesis', Psychological Bulletin, vol. 98, pp. 310-57.

Country Matters 2008, Social atlas of rural \& regional Australia, Bureau of Rural Sciences, Commonwealth of Australia, Canberra, viewed 14 April 2010, http://adl.brs.gov.au/socialatlas/. 
Dempsey, I \& Keen, D 2008, 'A review of processes and outcomes in family-centered services for children with a disability', Topics in Early Childhood Special Education, vol. 28, no. 1, pp. 42-52.

Drought Policy Review Expert Social Panel (DPRESP) 2008, It's about people: Changing perspectives on dryness. A report to government by an expert social panel, Department of Agriculture, Fisheries and Forestry, Canberra, September.

Dunst, C, Trivette, C \& Hamby, D 2007, 'Meta-analysis of family-centered helpgiving practices research', Mental Retardation and Developmental Disabilities Research Reviews, vol. 13, no. 4, pp. 370-78.

Fuller, A, McGraw, K \& Goodyear, M 1999, 'Bungy jumping through life: What young people say promotes well-being and resilience', Australian Journal of Guidance and Counselling, vol. 9, no. 1, pp. 159-68.

Grotberg, E 1995, A guide to promoting resilience in children: Strengthening the human spirit, Bernard van Leer Foundation, The Hague, Netherlands.

Landau, J 2007, 'Enhancing resilience: Families and communities as agents for change', Family Process, vol. 46, no. 3, pp. 351-65.

Landau, J \& Saul, J 2004, 'Facilitating family and community resilience in response to major disaster', in F Walsh \& M McGoldrick (eds), Living beyond loss, Norton, New York.

Lincoln, Y \& Guba, E 1985, Naturalistic inquiry, Sage, London.

Luthar, S 2006, 'Resilience in development: A synthesis of research across five decades', in D Cicchetti \& DJ Cohen (eds), Developmental psychopathology: Risk, disorder, and adaptation, 2nd edn, vol. 3, Wiley, New York, pp. 740-95.

Luthar, S \& Brown, P 2007, 'Maximizing resilience through diverse levels of inquiry: Prevailing paradigms, possibilities, and priorities for the future', Development and Psychopathology, vol. 19, pp. 931-55.

Maybery, D, Pope, R, Hodgins, G, Hitchenor, Y \& Shepherd, A 2009, 'Resilience and wellbeing of small inland communities: Community assets as key determinants', Rural Society, vol. 19, no. 4, pp. 326-39.

Mowbray, C, Woolley, M, Grogan-Kaylor, A, Gant, L, Gilster, M \& Shanks, T 2007, 'Neighborhood research from a spatially oriented strengths perspective', Journal of Community Psychology, vol. 35, no. 5, pp. 667-80.

Murray, G, Judd, F, Jackson, H, Fraser, C, Komiti, A, Hodgins, G, Pattison, P, Humprehys, J \& Robins, G 2004, 'Rurality and mental health: The role of accessibility', Australian \& New Zealand Journal of Psychiatry, vol. 38, no. 8, pp. 629-34.

Productivity Commission, Australia 2008, Inquiry into government drought support: Issues paper, Productivity Commission, Canberra, viewed 11 November 2008, www.pc.gov.au/ data/assets/pdf file/0007/81880/ government-drought-support-issues.pdf.

Resnick, M, Harris, L \& Blum, R 1993, 'The impact of caring and connectedness on adolescent health and well-being', Journal of Paediatrics \& Child Health, vol. 29, suppl. 1, s3-s9.

Rutter, M 1987, 'Psychosocial resilience and protective mechanisms', American Journal of Orthopsychiatry, vol. 57, no. 3, pp. 316-31.

Scales, T \& Streeter, C 2004, 'Asset building to sustain rural communities', in T Scales \& C Streeter (eds), Rural social work: Building and sustaining community assets, Brooks/Cole/Thomson Learning, Belmont, CA. 
69 | Gateways | Maybery, Pope, Hodgins \& Hitchenor

Walsh, F 2007, 'Traumatic loss and major disasters: Strengthening family and community resilience', Family Process, vol. 46, no. 2, pp. 207-27.

Werner, E \& Smith, R 1982, Vulnerable, but invincible: A longitudinal study of resilient children \& youth, McGraw-Hill, New York. 